\title{
Review Article \\ Obesity and Cancer Screening according to Race and Gender
}

\author{
Heather Bittner Fagan, ${ }^{1}$ Richard Wender, ${ }^{2}$ Ronald E. Myers, ${ }^{3}$ and Nicholas Petrelli ${ }^{4}$ \\ ${ }^{1}$ Department of Family and Community Medicine, Christiana Care Health System, 1400 North Washington Street, \\ Room 328, Wilmington, DE 19801, USA \\ ${ }^{2}$ Department of Family and Community Medicine, Jefferson Medical College, Thomas Jefferson University, \\ Philadelphia, PA 19107, USA \\ ${ }^{3}$ Division of Population Science, Department of Medical Oncology, Thomas Jefferson University, \\ Philadelphia, PA 19107, USA \\ ${ }^{4}$ Helen F. Graham Cancer Center, Christiana Care Health System, Newark, DE 19713, USA
}

Correspondence should be addressed to Heather Bittner Fagan, hbittner-fagan@christianacare.org

Received 2 August 2011; Accepted 24 October 2011

Academic Editor: Francesco Saverio Papadia

Copyright () 2011 Heather Bittner Fagan et al. This is an open access article distributed under the Creative Commons Attribution License, which permits unrestricted use, distribution, and reproduction in any medium, provided the original work is properly cited.

\begin{abstract}
The relationship between obesity and cancer screening varies by screening test, race, and gender. Most studies on cervical cancer screening found a negative association between increasing weight and screening, and this negative association was most consistent in white women. Recent literature on mammography reports no association with weight. However, some studies show a negative association in white, but not black, women. In contrast, obese/overweight men reported higher rates of prostate-specific antigen (PSA) testing. Comparison of prostate cancer screening, mammography, and Pap smears implies a gender difference in the relationship between screening behavior and weight. In colorectal cancer (CRC) screening, the relationship between weight and screening in men is inconsistent, while there is a trend towards lower CRC screening in higher weight women.
\end{abstract}

\section{Introduction}

Obesity, resulting from inactivity and poor nutrition, is second only to tobacco use as a risk factor for cancer [1]. Obesity is associated with increased mortality for all cancers combined, as well as for cancers of specific sites, including colon/rectum, prostate, breast, and cervix [2, 3]. Race and gender are also associated with poor outcomes for cancer $[4,5]$. Compared to their non-Hispanic white counterparts, black men and women are more likely to be obese and to have a higher cancer mortality rate [6-8]. Numerous studies have examined the biological pathways that link obesity to increased cancer risk, but biological pathways are unlikely to provide a complete explanation of the association of obesity and increased cancer mortality. Participation in cancer screening is an important determinant of cancer mortality, and there may be an association between obesity and use of some types of screening. This association seems to vary according to race, gender, and screening test. While numerous studies suggest that obesity constitutes an obstacle to cancer screening, [3, 9-17] the interplay between obesity and cancer screening is not clear.

Historically, blacks and women have been less likely to undergo cancer screening when compared to their nonHispanic white or male counterparts [18-21]. Obesity may be one reason for the disparity in screening among race/ethnicity and gender subgroups, either because obesity is more prevalent in these groups or because in some subgroups, it may have a more potent effect. The relationship to obesity and cancer screening is made complex by the fact that cancer screening tests are very different in terms of what is required of an individual in order to complete screening. The relationship between obesity and cancer screening may have a stronger negative association in certain cancer screening tests. For example, disparities appear more pronounced for endoscopic screening than for fecal occult blood test (FOBT) screening [19]. This situation may exist because endoscopic testing is more invasive or harder to do in obese patients relative to other screening tests. Furthermore, socioeconomic factors such as insurance status and health care access, 
which can be confounded with race/ethnicity and gender, may contribute to the disparity [19]. Efforts to measure the contribution of race/ethnicity and gender to variation in screening rates should take these factors into account.

In this review, we attempt to build a more comprehensive picture of the relationship of obesity and cancer screening by including the variables of race/ethnicity, gender, and screening test. Here, we review the available literature examining the interactions of race/ethnicity, gender, and obesity with cancer screening rates. Understanding the relationship of obesity and cancer screening relative to race/ethnicity and gender can inform efforts to identify and reduce disparities in cancer screening.

\section{Materials and Methods}

We reviewed articles which presented data on the relationship of any weight measure to screening for any of the following cancers: colon, breast, cervical, or prostate. The MEDLINE database search focused on 1996 through April 2011. First, we extracted 2,048 articles related to obesity, morbid obesity, overweight and BMI. From this group of articles we extracted those having to do with the diagnosis or prevention of neoplasms. We included various types of cancer screening tests (colonoscopy, sigmoidoscopy, gastrointestinal endoscopy, fecal occult blood testing, Pap smears, mammography, and prostate-specific antigen), as well as the more general term "mass screening". We further limited the search by using terms that describe articles as qualitative research or evaluation studies, resulting in 262 articles. Abstracts and manuscripts were used to exclude articles which did not examine the association between weight and cancer screening in order to obtain the final 29 articles. Studies were organized according to type of cancer screening and stratified according to gender and race. Tables 1,2 , and 3 present the studies on breast, cervical, and prostate cancer screening. Table 4 presents the studies of obesity and colorectal cancer screening.

\section{Results}

3.1. Cervical Cancer Screening. We identified one review of research on the relationship of obesity and cervical cancer screening [44] and three additional articles [22-24]. Twelve studies examined the relationship of obesity and screening for cervical cancer, and all of these studies found an association between increased body weight and decreased utilization of Pap smears [12-15, 25, 27-31, 45, 46]. Of the five studies which examined the association of obesity and cervical cancer screening in white women, all reported a negative association. In black women, six studies examined obesity and cervical cancer screening. Four studies reported no association, while two studies reported a negative association between obesity and Pap smear use in black women. Of note, one of these two studies [28] utilized data from the Black Women's Health Study which includes black women of high socioeconomic status which may be associated with different screening behavior. The other outlying study was a reanalysis of the same data set using different covariates and inclusion criteria $[15,25]$. In summary, the data seems to suggest a negative association between obesity and cervical cancer screening in white women which is not present, or not as strong in black women.

3.2. Breast Cancer Screening. We identified one review of research on the relationship of obesity and breast cancer screening [44], and five additional articles [12, 22-24, 29]. None of these 11 studies showed no negative association between weight and mammography use in women. In the three studies that stratified the obesity-screening relationship according to race $[16,17,27]$, in one study [17] obesity was associated with decreased utilization of mammography in white women and increased utilization in their black counterparts. In black women, two of these three studies found a positive association between obesity and mammography use, while one study found no effect in black women.

3.3. Prostate Cancer Screening. Four studies examined the association between obesity and prostate cancer screening, and all used prostate-specific antigen (PSA) testing as their outcome. Three of the four studies indicated that obese men were more likely to have had a PSA test [9-11] when compared with their normal-weight peers. One study examined obesity and PSA testing in a cohort of men from primary care practices and found a consistent association with obesity and increased PSA testing, regardless of race [10].

3.4. Colorectal Cancer Screening. Colorectal cancer (CRC) is currently the only cancer screening recommended for both men and women, and therefore, CRC is the only screening in which the impact of gender and obesity can be directly compared [47]. Sixteen studies were identified that examined the relationship of obesity and colorectal cancer (CRC) screening [22, 24, 32-43, 48, 49], but only six studies stratified the obesity-cancer screening relationship by gender $[35,36,39,40,42,43]$. In men, the relationship between obesity and CRC screening was inconsistent. In men, two studies $[36,43]$, indicated that obesity was associated with lower CRC screening rates. One study indicated that obesity was associated with higher endoscopic CRC screening rates in men [39], and three studies indicated no association in men $[35,40,42]$. In three studies, fecal occult blood testing (FOBT) was examined independently and there was no association between FOBT use and weight in men [35, $39,40]$. In women, the relationship between obesity and CRC screening was more consistent. In women, four studies demonstrated a negative association between obesity and CRC screening [36, 39, 40,43], and one study demonstrated higher rates of CRC screening in obese women [42], and one study showed no association [35]. One outlying study was a case-control study that identified cases from two tumor registries and may have had a selection bias towards women being more likely to screen. Four studies conducted on women reported that on endoscopy separately and in three of the four studies, obesity was negatively associated with screening [39, 40, 42, 43]. Three studies specifically reported 
TABLE 1: Cervical cancer screening and weight status.

\begin{tabular}{|c|c|c|c|}
\hline Study & Population/data source & Weight categories ${ }^{1}$ & Findings \\
\hline $\begin{array}{l}\text { Chang et al. 2010, } \\
{[22]}\end{array}$ & $\begin{array}{l}\text { Medicare and Veterans } \\
\text { Health Administration } \\
\text { (VHA) }\end{array}$ & OW and $\mathrm{OB}$ & $\begin{array}{l}\text { There was no significant association between Pap } \\
\text { smears and OW or OB. }\end{array}$ \\
\hline $\begin{array}{l}\text { Banerjea et al. 2008, } \\
{[23]}\end{array}$ & $\begin{array}{l}\text { Medical Expenditure Panel } \\
\text { Survey (MEPS) } 2003\end{array}$ & $\mathrm{OW}$ and $\mathrm{OB}$ & $\begin{array}{l}\text { OW and } \mathrm{OB} \text { were negatively associated with Pap smears } \\
(\mathrm{OR} 0.72 P<0.01) \text {. }\end{array}$ \\
\hline $\begin{array}{l}\text { Mitchell et al. 2008, } \\
{[24]}\end{array}$ & $\begin{array}{l}\text { Canadian Community } \\
\text { Health Survey, national } \\
\text { population-based } \\
\text { household survey in a } \\
\text { universal payor system. }\end{array}$ & OW, OBI, OBII, OBIII & $\begin{array}{l}\text { OW, OBI, OBII, and OBIII were negatively associated } \\
\text { with Pap smears. OR } 0.87(0.81-0.94) \text {, OR } 0.79 \\
(0.72-0.88) \text {, OR } 0.62(0.54-0.71) \text {, OR } 0.61(0.53-0.72) \text {. }\end{array}$ \\
\hline $\begin{array}{l}\text { Ferrante et al. 2007, } \\
\text { [12] }\end{array}$ & NHIS 2000 & OW, OBI, OBII, OBIII & $\begin{array}{l}\text { OBI and OBIII were negatively associated with Pap } \\
\text { smears. OR } 0.65(0.44-0.97) \text {, OR } 0.43(0.27-0.70) \text {. } \\
\text { There was no significant association between receipt of } \\
\text { Pap smears and OW and OBII }\end{array}$ \\
\hline Wu et al. 2006, [25] & NHIS 2000 & OW, OB, OBI, OBII, OBIII & $\begin{array}{l}\text { OBII was positively associated with underused Pap } \\
\text { smears in African-American women. OR } 1.93 \\
(1.03-3.01) \text {. } \\
\text { There was no significant association in OW, OBI, or } \\
\text { OBIII in African-American women. } \\
\text { There was no significant association between any } \\
\text { weight category and Pap smears for white women. }\end{array}$ \\
\hline Amy et al. 2006, [26] & $\begin{array}{l}\text { Purposeful sample. } \\
\text { Questionnaire } \\
\text { administered in focus } \\
\text { groups formed on weight } \\
\text { criteria. }\end{array}$ & $\begin{array}{l}\text { Other: BMI } 25-35,>35-45 \\
>55\end{array}$ & $\begin{array}{l}\text { There was significant association between receipt of } \\
\text { Pap smears and BMI }>55 \mathrm{~kg} / \mathrm{m}^{2}\left(x^{2}=9.98, P<0.02\right) \text {. } \\
\text { There were no significant associations between receipt } \\
\text { of Pap smears and BMI }>35-45 \text { or }>45-55 \text {. }\end{array}$ \\
\hline $\begin{array}{l}\text { Ferrante et al. 2006, } \\
\text { [13] }\end{array}$ & $\begin{array}{l}\text { Medical chart review of } \\
\text { urban FM practices (mostly } \\
\text { black and Hispanics) }\end{array}$ & $\begin{array}{l}\text { nonobese (normal and } \\
\text { OW), OBI, OBII, OBIII }\end{array}$ & $\begin{array}{l}\text { There were no significant associations between weight } \\
\text { status and Pap smears. }\end{array}$ \\
\hline $\begin{array}{l}\text { Ostbye et al. 2005, } \\
{[27]}\end{array}$ & $\begin{array}{l}\text { Health and Retirement } \\
\text { Study (HRS) and the Asset } \\
\text { and Health Dynamics } \\
\text { Among the Oldest Old } \\
\text { (AHEAD) }\end{array}$ & OW, OB, OBI, OBII, OBIII & $\begin{array}{l}\text { OW, OBI, OBII, OBIII were negatively associated with } \\
\text { Pap smears (ORs } 0.78,0.68,0.59,0.50)\end{array}$ \\
\hline Wee et al. 2005, [14] & 2000 NHIS data & OW, OB, OBI, OBII, OBIII & $\begin{array}{l}\text { OBIII was negatively associated with Pap smears in } \\
\text { white women only. RR } 0.92(0.83-0.99) \text {. } \\
\text { There were no significant associations between weight } \\
\text { status and Pap smears in black or Hispanic women. }\end{array}$ \\
\hline Datta et al. 2005, [28] & $\begin{array}{l}\text { Black Women's Health } \\
\text { Study 1995, USA, mailed } \\
\text { questionnaire, subscribers } \\
\text { to Essence, Black Women's } \\
\text { Professional Association } \\
\text { and friends/relatives of } \\
\text { participants. }\end{array}$ & $\mathrm{OW}$ and $\mathrm{OB}$ & $\begin{array}{l}\text { OB was associated with increased rate of no Pap smear } \\
\text { in last } 2 \text { years (OR } 1.4-1.7) \text {. } \\
\text { No association between OW and Pap smears in last } 2 \\
\text { years. }\end{array}$ \\
\hline $\begin{array}{l}\text { Coughlin et al. 2004, } \\
\text { [29] }\end{array}$ & $\begin{array}{l}\text { BRFSS 1999, US women } \\
\geq 40\end{array}$ & OW and $\mathrm{OB}$ & $\begin{array}{l}\text { OB was negatively associated with Pap smear use in the } \\
\text { last } 2 \text { years }(85.9 P<0.05)\end{array}$ \\
\hline Wee et al. 2000, [15] & NHIS 1994 & OW, OB, OBI, OBII, OBIII & $\begin{array}{l}\text { OW, OBI, OBII, and OBIII were negatively associated } \\
\text { with Pap smears in white women: } 3.4 \%(-6.4 \% \text { to } \\
-0.5 \%),-9.4 \%(-13.5 \% \text { to }-5.2 \%),-8.3 \%(-14.2 \% \\
\text { to }-2.3 \%),-8.8 \%(-16.9 \% \text { to }-0.7 \%) \text {. } \\
\text { There was no association between weight status and } \\
\text { receipt of Pap smears in black women. }\end{array}$ \\
\hline
\end{tabular}

${ }^{1}$ Predictors: OW: Overweight, OB: Obese, OBI: Obese I, OBII: Obese II, OBIII: Obese III. 
TABLE 2: Mammography use and weight status.

\begin{tabular}{|c|c|c|c|}
\hline Study & Population/data Source & Weight categories $^{1}$ & Findings \\
\hline $\begin{array}{l}\text { Chang et al. } \\
2010,[22]\end{array}$ & $\begin{array}{l}\text { National Medicare claims } \\
\text { data (Medicare), Veterans } \\
\text { Health Administration data } \\
\text { (VHA) }\end{array}$ & $\mathrm{OW}$ and $\mathrm{OB}$ & $\begin{array}{l}\text { OW in Medicare beneficiaries was positively associated } \\
\text { with mammography in } \mathrm{OR}=1.13 P=.02 \text {, but not in } \\
\text { VHA data. } \\
\text { There was no significant association of mammography } \\
\text { in OB (VHA or Medicare) or OW (VHA). }\end{array}$ \\
\hline $\begin{array}{l}\text { Banerjea et al. } \\
2008,[23]\end{array}$ & $\begin{array}{l}\text { Medical Expenditure Panel } \\
\text { Survey (MEPS) } 2003\end{array}$ & $\mathrm{OW}$ and $\mathrm{OB}$ & $\begin{array}{l}\text { There were no significant associations between } \\
\text { mammography use and OB or OW. }\end{array}$ \\
\hline $\begin{array}{l}\text { Mitchell et al. } \\
\text { 2008, [24] }\end{array}$ & $\begin{array}{l}\text { Canadian Community } \\
\text { Health Survey }\end{array}$ & OW, OB, OBI, OBII, OBIII & $\begin{array}{l}\text { There were no significant associations between } \\
\text { mammography use and OW, OB (including OBI, OBII, } \\
\text { OBIII). }\end{array}$ \\
\hline $\begin{array}{l}\text { Ferrante et al. } \\
2007,[12]\end{array}$ & $\begin{array}{l}\text { National Health Interview } \\
\text { Survey (NHIS) } 2000\end{array}$ & OB, OW, OBI, OBII, OBIII & $\begin{array}{l}\text { OBIII was negatively associated with mammography. } \\
(62.3 \% P=0.0084) \text {. } \\
\text { There were no associations between mammography } \\
\text { and weight status in OW, OBI, or OBII women. }\end{array}$ \\
\hline $\begin{array}{l}\text { Amy et al. 2006, } \\
{[26]}\end{array}$ & $\begin{array}{l}\text { Purposeful sample, } \\
\text { face-to-face questionnaire } \\
\text { in focus groups formed } \\
\text { according to weight status }\end{array}$ & BMI 25-35, >35-45, >55 & $\begin{array}{l}\text { There were no significant associations between } \\
\text { mammogram use and increasing BMI category. }\end{array}$ \\
\hline $\begin{array}{l}\text { Ferrante et al. } \\
2006,[13]\end{array}$ & $\begin{array}{l}\text { Medical chart review, } \\
\text { urban FM practices, mostly } \\
\text { black and Hispanic }\end{array}$ & $\begin{array}{l}\text { OBI, OBII, OBIII, } \\
\text { nonobese (normal and } \\
\text { overweight collapsed) }\end{array}$ & $\begin{array}{l}\text { There was no significant association between } \\
\text { mammography use and weight status. }\end{array}$ \\
\hline $\begin{array}{l}\text { Zhu et al. 2006, } \\
{[16]}\end{array}$ & NHIS 2000 & OW, OBI, OBII, OBIII & $\begin{array}{l}\text { There was no significant association between weight } \\
\text { status and mammography in white or black women. }\end{array}$ \\
\hline $\begin{array}{l}\text { Ostbye et al. } \\
2005,[27]\end{array}$ & $\begin{array}{l}\text { Health and Retirement } \\
\text { Study (HRS) and the Asset } \\
\text { and Health Dynamics } \\
\text { Among the Oldest Old } \\
\text { (AHEAD) }\end{array}$ & $\mathrm{OW}$ and $\mathrm{OB}$ & $\begin{array}{l}\text { OBI, OBII, and OBIII were negatively associated with } \\
\text { mammogram use (OR } 0.73,0.69,0.59 \text {, resp.). } \\
\text { There were no significant associations between } \\
\text { mammography use and OW. }\end{array}$ \\
\hline $\begin{array}{l}\text { Coughlin et al. } \\
2004,[29]\end{array}$ & $\begin{array}{l}\text { Behaviorial Risk Factor } \\
\text { Surveillance Survey } \\
\text { (BRFSS) } 1999\end{array}$ & $\mathrm{OW}$ and $\mathrm{OB}$ & $\begin{array}{l}\text { OB was negatively associated with mammography use. } \\
74.6 \% P<0.001 \text {. }\end{array}$ \\
\hline $\begin{array}{l}\text { Wee et al. 2004, } \\
{[17]}\end{array}$ & NHIS 1998 & OW, OBI, OBII, OBIII & $\begin{array}{l}\text { OBII was negatively associated with mammography in } \\
\text { white women. OR } 0.83(0.68-0.96) \text {. } \\
\text { OW and OBII were positively associated with } \\
\text { mammography in black women. OR } 1.19(1.01-1.32) \text {, } \\
\text { OR } 1.37(1.13-1.50) \text {. } \\
\text { There were no other significant associations. }\end{array}$ \\
\hline $\begin{array}{l}\text { Wee et al. 2000, } \\
{[15]}\end{array}$ & NHIS 1994 & OW, OB, OBI, OBII, OBIII & $\begin{array}{l}\text { There was no association of weight status and } \\
\text { mammography in white or black women. }\end{array}$ \\
\hline $\begin{array}{l}\text { Fontaine et al. } \\
\text { 2001, [30] }\end{array}$ & National Data 1998 & OW, OBI, OBII, OBIII & $\begin{array}{l}\text { OW and OBIII were positively associated with } \\
\text { mammography use. } \\
\text { There were no significant associations between OBI, } \\
\text { OBII, and mammography use. }\end{array}$ \\
\hline $\begin{array}{l}\text { Fontaine et al. } \\
1998,[31]\end{array}$ & $\begin{array}{l}\text { National Data Set }(>80 \% \\
\text { white) } 1992\end{array}$ & OW, OB & $\begin{array}{l}\text { There was no significant association between weight } \\
\text { status and mammography use. }\end{array}$ \\
\hline
\end{tabular}

${ }^{1}$ Predictors: OW: Overweight, OB: Obese (unless otherwise specified, includes OBI, OBII, OBIII), OBI: Obese I, OBII: Obese II, OBIII: Obese III.

FOBT use in women: one indicated a negative association between obesity and screening, while the other two indicated no association between obesity and FOBT use in women $[35,39,40]$. These studies suggest that body weight may have a different impact on the likelihood of undergoing CRC screening in men and women. In women, the majority of the literature suggests a negative association between obesity and CRC screening, whereas in men there is little consistency in the association of obesity and CRC screening.
While many studies examine the relationship of obesity to cancer screening, we identified only two that explored the impact of race and obesity on CRC screening. In the New York Cancer Project, Vlahov et al. [38] reported that obesity did not impact CRC screening in blacks, whites, or Hispanics. These authors did not examine men and women separately. Leone et al. [34] found that obesity was associated with lower rates of CRC screening in white women but not their black counterparts. No studies were identified in the 
Table 3: Prostate-specific antigen testing and weight status.

\begin{tabular}{|c|c|c|c|}
\hline Study & Population/data Source & Weight categories ${ }^{1}$ & Findings \\
\hline Muus et al. 2009, [32] & $\begin{array}{l}\text { National face-to-face } \\
\text { survey of American Indian } \\
\text { and Alaskan men in USA }\end{array}$ & OW, OB, OBI, OBII, OBIII & $\begin{array}{l}\text { There was no significant association between receipt of } \\
\text { PSA and OW, OB. }\end{array}$ \\
\hline Scales et al. 2007, [9] & BRFSS 2002, men $\geq 40$ & OW and $\mathrm{OB}$ & $\begin{array}{l}\text { OW was positively associated with PSA testing. OR } 1.46 \\
{[1.33-1.61] \text {. }}\end{array}$ \\
\hline $\begin{array}{l}\text { Fowke et al. 2006, } \\
{[10]}\end{array}$ & $\begin{array}{l}\text { In-person interviews, men } \\
\text { from } 25 \text { health centers in } \\
\text { USA ( } 85 \% \text { black) }\end{array}$ & OW, OBI, OBII, OBIII & $\begin{array}{l}\text { OW, OBI, OBII were positively associated with PSA } \\
\text { testing in black men. } 1.26(1.10-1.44), 1.38(1.18-1.62) \text {, } \\
1.37(1.10-1.72) \\
\text { OBII was positively associated with PSA testing in white } \\
\text { men. OR } 1.67 \text { [1.06-2.63]. } \\
\text { There were no other significant associations. }\end{array}$ \\
\hline $\begin{array}{l}\text { Fontaine et al. 2005, } \\
\text { [11] }\end{array}$ & BRFSS 2001, men $\geq 50$ & OW, OBI, OBII, OBIII & $\begin{array}{l}\text { OW, OBI, OBII, and OBIII were positively associated } \\
\text { with PSA testing. OR } 1.13 \text { [1.04-1.35], OR } 1.26 \\
{[1.06-1.36], 1.14 \text { [1.02-1.06]. }}\end{array}$ \\
\hline
\end{tabular}

${ }^{1}$ Predictors: OW: Overweight, OB: Obese, OBI: Obese I, OBII: Obese II, OBIII: Obese III.

CRC screening literature which examined the relationship of obesity and screening according to both race and gender.

\section{Discussion}

The relationship between obesity and cancer screening is complex. The type of screening test strongly influences this relationship. In cervical cancer screening, increasing weight is consistently associated with lower rates of obtaining Pap smears. In breast cancer screening, there is a less consistent association between increased weight and decreased mammography. Conversely, prostate cancer screening, measured by PSA testing, seems to increase as weight increases. Comparing cervical, breast, and prostate cancer, men seem to behave opposite of women, suggesting that gender influences the relationship between screening and weight. However, CRC screening, the only example of cancer screening which would allow comparison by gender, does not elucidate the impact of gender. In fact, the relationship of weight status and screening in CRC is the least consistent of all the screening tests. Other variables, such as race, may be an important source of this inconsistency.

In mammography and Pap smears, race affects the relationship between screening and weight. Increased weight appears to be more of a barrier in white women in both mammography and Pap smears. In part, this may be explained by differences in perception of weight. Cancer screening is a behavioral outcome, influenced by personal factors. Women who see themselves as too heavy are more likely to feel embarrassment regarding examination [50, 51]. White and black women perceive their weight differently. White women consider themselves overweight at a lower BMI, compared to black women $[52,53]$. So, white women may become resistant to screening at a lower BMI. White women report body dissatisfaction at a lower BMI relative to their black counterparts $[54,55]$. This may create a "dose-response" effect of obesity and screening behavior with different thresholds for different races, at least in women, which would be consistent with a similar "dose-response" effect in cancer morbidity and mortality. However, this race effect in women is not seen in men.

The association of weight status and prostate cancer is relatively unique in that there appears to be a positive association with testing as weight increases, and this effect persists when men are stratified by race. This may be explained by differences in access and utilization of health care. As weight increases, other comorbid conditions increase, so that heavier men may be higher utilizers of health care. By having more encounters with the health care system, these men are more likely to be counseled or encouraged to be tested.

CRC screening, the only screening which permits the examination of both race and gender (e.g., white men, white women, black men, and black women) should elucidate the combined and often contradictory effects of both race and gender on cancer screening. However, CRC screening reveals a confusing pattern of association between weight status and testing. CRC screening is a more complex test to study as there are several test choices, and this implicitly makes for more complicated analyses. Indeed, the literature varies in outcome reported with most studies reporting overall screening (stool testing or endoscopy) and some studies reporting these test options separately. Those studies which distinguish according to endoscopy and stool testing suggest that endoscopy, not FOBT, is more likely influenced by weight status. So, any differential effects based on race or gender may be suppressed when examining a composite variable such as overall CRC screening (endoscopy and stool blood test).

With the exception of cervical cancer screening, there is no clear, consistent pattern of association between obesity and cancer screening. There were no studies of obesity and cancer screening which examined the combined effect of race/ethnicity and gender. This is an important gap in the literature, as finding from this review suggests that screening behavior across race-gender subgroups, for example, black men, black women, white men, and white women, is likely to be very different.

Utilization and/or access to health care are important determinants of cancer screening $[34,41]$. However, such 
TABLE 4: Colorectal cancer screening and weight status.

\begin{tabular}{|c|c|c|c|c|}
\hline Study & Population/data source & $\begin{array}{l}\text { Weight } \\
\text { categories }^{1}\end{array}$ & Outcome & Findings \\
\hline $\begin{array}{l}\text { Chang et al. 2010, } \\
{[22]}\end{array}$ & $\begin{array}{l}\text { National Medicare Claims } \\
\text { (Medicare), Veterans } \\
\text { Health Administration } \\
\text { (VHA), } \geq 65 \text { years old }\end{array}$ & OW and $\mathrm{OB}$ & Colorectal cancer screening & $\begin{array}{l}\text { There was increased CRC screening in } \\
\text { overweight VHA care recipients OR } 1.12 \\
P=0.002 \text {. } \\
\text { There were no other significant } \\
\text { associations between CRC screening and } \\
\text { OB (VHA and Medicare) and OW } \\
\text { Medicare beneficiaries. }\end{array}$ \\
\hline $\begin{array}{l}\text { Adams-Campbell } \\
\text { et al. 2010, [33] }\end{array}$ & $\begin{array}{l}\text { Black Women's Health } \\
\text { Study }\end{array}$ & OW and $\mathrm{OB}$ & Colonoscopy in past 2 years & $\begin{array}{l}\text { There were no significant associations } \\
\text { between colonoscopy and OW, OB. }\end{array}$ \\
\hline Leone 2009, [34] & NHIS 2005, women only & $\begin{array}{l}\text { Collapsed OW } \\
\text { and OB }\end{array}$ & $\begin{array}{l}\text { Colorectal cancer screening } \\
\text { colonoscopy, endoscopy, or } \\
\text { FOBT }\end{array}$ & $\begin{array}{l}\text { OB was negatively associated with CRC } \\
\text { screening in white but not black women. } \\
\text { OR-0.66 } P=0.001 \text {. }\end{array}$ \\
\hline $\begin{array}{l}\text { Muus et al. 2009, } \\
\text { [32] }\end{array}$ & $\begin{array}{l}\text { National face-to-face } \\
\text { survey, American Indian } \\
\text { and Alaskan native men in } \\
\text { USA. }\end{array}$ & $\begin{array}{l}\text { OW, OB, OBI, } \\
\text { OBII, OBIII }\end{array}$ & FOBT & $\begin{array}{l}\text { There were no significant associations } \\
\text { between receipt of FOBT and OW, OB (I, } \\
\text { II, III). }\end{array}$ \\
\hline $\begin{array}{l}\text { Banerjea et al. } \\
2008,[23]\end{array}$ & $\begin{array}{l}\text { Medical Expenditure } \\
\text { Survey (MEPS) } 2003 \text { and } \\
\text { subset of NHIS (women } \\
\text { only) }\end{array}$ & OW and $\mathrm{OB}$ & Colorectal cancer screening & $\begin{array}{l}\text { OW was negatively associated with CRC } \\
\text { screening. OR } 0.80 \text { [0.66-0.97]. }\end{array}$ \\
\hline $\begin{array}{l}\text { Mitchell et al. } \\
\text { 2008, [24] }\end{array}$ & $\begin{array}{l}\text { Canadian Community } \\
\text { Health Survey }\end{array}$ & $\begin{array}{l}\text { OW, OB, OBI, } \\
\text { OBII, OBIII }\end{array}$ & FOBT & $\begin{array}{l}\text { There was no significant association } \\
\text { between receipt of FOBT testing and OW, } \\
\text { OB (I, II, III). }\end{array}$ \\
\hline $\begin{array}{l}\text { James et al. 2008, } \\
\text { [35] }\end{array}$ & $\begin{array}{l}\text { Wellness for } \\
\text { African-Americans through } \\
\text { Churches (WATCH) }\end{array}$ & $\begin{array}{l}\text { OW, OB, OBI, } \\
\text { OBII, OBIII }\end{array}$ & FOBT & $\begin{array}{l}\text { There was no significant association } \\
\text { between FOBT and OW, or OB (I, II, III) } \\
\text { in men or women. }\end{array}$ \\
\hline $\begin{array}{l}\text { James et al. 2008, } \\
\text { [35] }\end{array}$ & WATCH & $\begin{array}{l}\text { OW, OB, OBI, } \\
\text { OBII, OBIII }\end{array}$ & Colorectal cancer screening & $\begin{array}{l}\text { There was no significant association } \\
\text { between receipt of overall CRC screening } \\
\text { and OW, or OB (I, II, III) in men or } \\
\text { women. }\end{array}$ \\
\hline $\begin{array}{l}\text { James et al. 2008, } \\
\text { [35] }\end{array}$ & WATCH & $\begin{array}{l}\text { OW, OB, OBI, } \\
\text { OBII, OBIII }\end{array}$ & Sigmoidoscopy & $\begin{array}{l}\text { There was no significant association } \\
\text { between receipt of sigmoidoscopy and } \\
\text { OW, or OB (I, II, III) for men or women. }\end{array}$ \\
\hline $\begin{array}{l}\text { James et al. 2008, } \\
\text { [35] }\end{array}$ & WATCH & $\begin{array}{l}\text { OW, OB, OBI, } \\
\text { OBII, OBIII }\end{array}$ & Past-year CRC screening & $\begin{array}{l}\text { There was no significant association } \\
\text { between past-year CRC screening and } \\
\text { OW, or OB (I, II, III) in women or men. }\end{array}$ \\
\hline $\begin{array}{l}\text { Ferrante et al. } \\
2006,[36]\end{array}$ & $\begin{array}{l}\text { Medical records of New } \\
\text { Jersey and Pennsylvania } \\
\text { primary care practice } \\
\text { patients } \geq 50\end{array}$ & $\begin{array}{l}\text { Collapsed OW } \\
\text { and OB }\end{array}$ & Colorectal cancer screening & $\begin{array}{l}\text { OB was negatively associated with CRC } \\
\text { screening. OR } 0.75 P=0.004\end{array}$ \\
\hline $\begin{array}{l}\text { Menis et al. 2006, } \\
\text { [37] }\end{array}$ & $\begin{array}{l}\text { Maryland Cancer Survey } \\
\text { 2002, population-based } \\
\text { random-digit dial } \\
\text { telephone survey }\end{array}$ & $\mathrm{OB}$ and $\mathrm{OW}$ & Colorectal cancer screening & $\begin{array}{l}\text { There was no significant association of } \\
\text { CRC screening with OW or OB. }\end{array}$ \\
\hline $\begin{array}{l}\text { Vlahov et al. 2005, } \\
{[38]}\end{array}$ & New York Cancer Project & OB only & Endoscopy & $\begin{array}{l}\text { There was no significant association } \\
\text { between obesity and endoscopy. }\end{array}$ \\
\hline $\begin{array}{l}\text { Heo et al. 2004, } \\
\text { [39] }\end{array}$ & $\begin{array}{l}\text { Behaviorial Risk Factor } \\
\text { Surveillance Survey } \\
\text { (BRFSS) } 2001\end{array}$ & $\begin{array}{l}\text { OW, OB, OBI, } \\
\text { OBII, OBIII }\end{array}$ & FOBT & $\begin{array}{l}\text { There were no significant associations } \\
\text { between BMI category and in men or } \\
\text { women. }\end{array}$ \\
\hline $\begin{array}{l}\text { Heo et al. 2004, } \\
\text { [39] }\end{array}$ & BRFSS 2001 & $\begin{array}{l}\text { OW, OB, OBI, } \\
\text { OBII, OBIII }\end{array}$ & Sigmoidoscopy & $\begin{array}{l}\text { OW and OBII were positively associated } \\
\text { with sigmoidoscopy in last } 5 \text { years in } \\
\text { men. OR } 1.25[1.05-1.51], 1.21 \\
{[1.03-1.75] \text {. }} \\
\text { OBI and OBII were negatively associated } \\
\text { with sigmoidoscopy in last } 5 \text { years in } \\
\text { women. OR } 0.86 \text { [0.78-0.94], OR } 0.88 \\
{[0.79-0.99] .}\end{array}$ \\
\hline
\end{tabular}


Table 4: Continued.

\begin{tabular}{|c|c|c|c|c|}
\hline Study & Population/data source & $\begin{array}{l}\text { Weight } \\
\text { categories }^{1}\end{array}$ & Outcome & Findings \\
\hline $\begin{array}{l}\text { Rosen and } \\
\text { Schneider 2004, } \\
{[40]}\end{array}$ & BRFSS 1999 & $\begin{array}{l}\text { Morbidly OB } \\
(\mathrm{BMI} \geq 35)\end{array}$ & Endoscopy & $\begin{array}{l}\text { Morbid obesity was negatively associated } \\
\text { with endoscopy in women only. RD }-4.9 \\
{[-7.7 \text { to }-1.9] \text {. }} \\
\text { There was no significant association } \\
\text { between morbid obesity and endoscopy } \\
\text { in men. }\end{array}$ \\
\hline $\begin{array}{l}\text { Rosen and } \\
\text { Schneider 2004, } \\
{[40]}\end{array}$ & BRFSS 1999 & $\begin{array}{l}\text { Morbidly OB } \\
(\mathrm{BMI} \geq 35)\end{array}$ & FOBT & $\begin{array}{l}\text { Morbid obesity in women only was } \\
\text { negatively associated with FOBT. RD - } \\
3.7[-7.7 \text { to }-1.9] \text {. } \\
\text { There was no significant association } \\
\text { between FOBT and morbid obesity in } \\
\text { men. }\end{array}$ \\
\hline $\begin{array}{l}\text { Rosen and } \\
\text { Schneider 2004, } \\
{[40]}\end{array}$ & BRFSS 1999 & $\begin{array}{l}\text { Morbidly OB } \\
(\mathrm{BMI} \geq 35)\end{array}$ & Colorectal cancer screening & $\begin{array}{l}\text { Morbid obesity in women only was } \\
\text { negatively associated with overall CRC } \\
\text { screening. RD }-5.6[-8.5 \text { to }-2.6] \text {. } \\
\text { There was no association between overall } \\
\text { CRC screening and morbid obesity in } \\
\text { men. }\end{array}$ \\
\hline $\begin{array}{l}\text { Seeff et al. 2004, } \\
{[41]}\end{array}$ & NHIS 2000 & OW and $\mathrm{OB}$ & Overall CRC & $\begin{array}{l}\text { There were no significant associations } \\
\text { between receipt of CRC screening and } \\
\text { OW or OB. }\end{array}$ \\
\hline $\begin{array}{l}\text { Seeff et al. 2004, } \\
\text { [41] }\end{array}$ & NHIS 2000 & OW and $\mathrm{OB}$ & FOBT & $\begin{array}{l}\text { There was no significant association } \\
\text { between receipt of FOBT and OW or OB. }\end{array}$ \\
\hline $\begin{array}{l}\text { Seeff et al. 2004, } \\
\text { [41] }\end{array}$ & NHIS 2000 & OW and $\mathrm{OB}$ & Endoscopy & $\begin{array}{l}\text { There was no significant association } \\
\text { between receipt of endoscopy and OW or } \\
\text { OB. }\end{array}$ \\
\hline $\begin{array}{l}\text { Slattery et al. 2004, } \\
\text { [42] }\end{array}$ & $\begin{array}{l}2 \text { population-based } \\
\text { case-control studies of } \\
\text { colorectal cancer patients, } \\
\text { interviewer-administered } \\
\text { questionnaire }\end{array}$ & OW and $\mathrm{OB}$ & Sigmoidoscopy & $\begin{array}{l}\text { OW and OB in women were positively } \\
\text { associated with sigmoidoscopy (OR } 1.8 \\
\text { and } 2.3 \text {, resp., } P<0.01 \text { ). } \\
\text { There was no significant association } \\
\text { between sigmoidoscopy and OW or OB } \\
\text { in men. }\end{array}$ \\
\hline $\begin{array}{l}\text { Chao et al. 2004, } \\
{[43]}\end{array}$ & $\begin{array}{l}\text { Cancer Prevention Study } \\
\text { (CPS) II Nutrition Cohort } \\
1997\end{array}$ & $\begin{array}{l}\text { OW and OB, } \\
\text { collapsed OBI } \\
\text { and II, morbid } \\
\text { obesity } \geq 40\end{array}$ & Endoscopy & $\begin{array}{l}\text { OBI and OBII were negatively associated } \\
\text { with endoscopy in men. OR } 0.88 \\
{[.82-.94] \text {. }} \\
\text { OBI and OBII were negatively associated } \\
\text { with endoscopy in women. OR } 0.8 \\
{[.81-.91] \text {. }} \\
\text { Morbid obesity in women was negatively } \\
\text { associated with endoscopy. OR } 0.71 \\
{[0.59-0.85] \text {. }}\end{array}$ \\
\hline
\end{tabular}

${ }^{1}$ Predictors: OW: Overweight, OB: Obese, OBI: Obese I, OBII: Obese II, OBIII: Obese III.

factors are difficult to measure and control for in small data sets. So, smaller studies often cannot include these measures, and this is a particular problem in analyzing racial subgroups which are likely to be a small subset. Obesity is more prevalent in minority and underserved groups, who have less access to health care. Different patterns of access and utilization in weight groups are likely to confound the relationship of obesity and cancer screening, making interpretation of the literature even more challenging.

Physician recommendation is an extremely important determinant of CRC screening [56-64]. However, physicians often have negative beliefs about obese patients such as the belief that the patient lacks self-control and that the patient is unlikely to make recommended behavior changes $[50,51,65]$. In addition, a patient's obesity appears to change the quality of the office visit. Bertakis and Azari demonstrated that the qualitative content of a visit is different in obese patients compared to their normal-weight counterparts [66]. With obese patients, the visit included less educational time and focused more on technical tasks such as physical examination. This suggests that doctors may devote less time and effort in discussions such as cancer screening. Obese patients, when questioned about satisfaction with their medical care prior to a new patient visit, were less satisfied with their medical care compared to their normal-weight counterparts [66]. This suggests 
a preexisting dissatisfaction which could mean that obese patients arrive to the physician's office less ready to screen. If obese patients have any particular reluctance to screen and there is less time devoted to addressing those barriers or concerns, the likely result would be lower screening. Yet Ferrante et al. found that lower rates of cancer screening persist even after controlling for physician recommendation [12] suggesting that there may be still more to the picture.

There are some obvious differences in the relationship between weight and screening in different types of screening tests. Obese women perceive their weight as a barrier to screening, and these women cite negative attitudes of providers and inappropriately sized equipment as specific concerns [26]. These concerns seem more likely to be activated in the case of cervical cancer screening.

The relationship between obesity and cervical cancer screening is consistently negative. In contrast, the relationship between obesity and prostate cancer screening is generally positive. A blood test such as PSA is relatively easy to do, whereas cervical cancer screening is invasive and includes exposure of intimate body parts to a physician with whom the patient expects to have an ongoing relationship. So, the invasiveness or embarrassment associated with testing may be important.

The data review on prostate cancer screening and colorectal cancer screening suggests that men may be more resistant to any barriers presented by obesity. In one of the studies where there is a positive relationship between obesity and screening in men, this effect was reduced when the authors controlled for hypertension and hyperlipidemia [10]. Perhaps, for men, obesity-related conditions increase access or exposure to the health care system and, therefore, obesity facilitates cancer screening in men.

\section{Conclusions}

Inconsistent methods may be a significant source of variation in this literature. In fact, two studies examined the same data set and found different outcomes based on such different inclusion/exclusion criteria $[14,25]$. More research is needed to create a comprehensive understanding of obesity and cancer screening. Specifically, work is needed to examine obesity and cancer screening in race-gender subgroups such as white men, white women, black men, and black women, and such an analysis needs to account for the effects of the doctor-patient relationship, access to care, and type of screening test. Regardless of effect on screening, obesity is clearly associated with increased cancer morbidity and mortality. So, as obesity becomes increasingly prevalent, it becomes increasingly important to understand and eliminate barriers to screening in obese individuals.

\section{Conflict of Interests}

All authors declare that there are no competing financial interests in relation to the work described.

\section{Acknowledgments}

The authors would like to acknowledge Madeleine Turley for her help with paper preparation and to acknowledge Barbara Henry, medical librarian for her help with the literature search. This work was supported by the American Cancer Society Cancer Control Career Development Award CCCDA-08-107-01.

\section{References}

[1] American Cancer Society, Cancer Facts and Figures 2007, American Cancer Society, Atlanta, Ga, USA, 2007.

[2] E. E. Calle, C. Rodriguez, K. Walker-Thurmond, and M. J. Thun, "Overweight, obesity, and mortality from cancer in a prospectively studied cohort of U.S. Adults," New England Journal of Medicine, vol. 348, no. 17, pp. 1625-1638, 2003.

[3] W. C. Buschemeyer III and S. J. Freedland, "Obesity and prostate cancer: epidemiology and clinical implications," European Urology, vol. 52, no. 2, pp. 331-343, 2007.

[4] A. Nelson, "Unequal treatment: confronting racial and ethnic disparities in health care," Journal of the National Medical Association, vol. 94, no. 8, pp. 666-668, 2002.

[5] E. Ward, A. Jemal, V. Cokkinides et al., "Cancer disparities by race/ethnicity and socioeconomic status," Ca-A Cancer Journal for Clinicians, vol. 54, no. 2, pp. 78-93, 2004.

[6] American Cancer Society, Colorectal Cancer Facts and Figures 2008-2010, American Cancer Society, Atlanta, Ga, USA, 2008.

[7] C. L. Ogden, M. D. Carroll, L. R. Curtin, M. A. McDowell, C. J. Tabak, and K. M. Flegal, "Prevalence of overweight and obesity in the United States, 1999-2004," Journal of the American Medical Association, vol. 295, no. 13, pp. 1549-1555, 2006.

[8] J. M. Gill, H. B. Fagan, B. Townsend, and A. G. Mainous, "Impact of providing a medical home to the uninsured: evaluation of a statewide program," Journal of Health Care for the Poor and Underserved, vol. 16, no. 3, pp. 515-535, 2005.

[9] C. D. Scales Jr., L. H. Curtis, R. D. Norris, K. A. Schulman, P. Dahm, and J. W. Moul, "Relationship between body mass index and prostate cancer screening in the United States," Journal of Urology, vol. 177, no. 2, pp. 493-498, 2007.

[10] J. H. Fowke, L. B. Signorello, W. Underwood III, F. A. M. Ukoli, and W. J. Blot, "Obesity and prostate cancer screening among African-American and Causian men," Prostate, vol. 66, no. 13, pp. 1371-1380, 2006.

[11] K. R. Fontaine, M. Heo, and D. B. Allison, "Obesity and prostate cancer screening in the USA," Public Health, vol. 119, no. 8, pp. 694-698, 2005.

[12] J. M. Ferrante, P. H. Chen, B. F. Crabtree, and D. Wartenberg, "Cancer screening in women. Body mass index and adherence to physician recommendations," American Journal of Preventive Medicine, vol. 32, no. 6, pp. 525-531, 2007.

[13] J. M. Ferrante, P. H. Chen, and A. Jacobs, "Breast and cervical cancer screening in obese minority women," Journal of Women's Health, vol. 15, no. 5, pp. 531-541, 2006.

[14] C. C. Wee, R. S. Phillips, and E. P. McCarthy, "BMI and cervical cancer screening among white, African-American, and hispanic women in the United States," Obesity Research, vol. 13, no. 7, pp. 1275-1280, 2005.

[15] C. C. Wee, E. P. McCarthy, R. B. Davis, and R. S. Phillips, "Screening for cervical and breast cancer: is obesity an unrecognized barrier to preventive care?" Annals of Internal Medicine, vol. 132, no. 9, pp. 697-704, 2000. 
[16] K. Zhu, H. Wu, I. Jatoi, J. Potter, and C. Shriver, "Body mass index and use of mammography screening in the United States," Preventive Medicine, vol. 42, no. 5, pp. 381-385, 2006.

[17] C. C. Wee, E. P. McCarthy, R. B. Davis, and R. S. Phillips, "Obesity and breast cancer screening," Journal of General Internal Medicine, vol. 19, no. 4, pp. 324-331, 2004.

[18] American Cancer Society, Cancer Prevention and Early Detection Facts and Figures 2008, American Cancer Society, Atlanta, Ga, USA, 2008.

[19] A. F. Jerant, J. J. Fenton, and P. Franks, "Determinants of racial/ethnic colorectal cancer screening disparities," Archives of Internal Medicine, vol. 168, no. 12, pp. 1317-1324, 2008.

[20] American Cancer Society, Cancer Prevention and Early Detection Facts and Figures 2009, American Cancer Society, Atlanta, Ga, USA, 2009.

[21] American Cancer Society, Cancer Prevention and Early Detection Facts and Figures 2010, 2011.

[22] V. W. Chang, D. A. Asch, and R. M. Werner, "Quality of care among obese patients," Journal of the American Medical Association, vol. 303, no. 13, pp. 1274-1281, 2010.

[23] R. Banerjea, P. Findley, and U. Sambamoorthi, "Disparities in preventive care by body mass index categories among women," Women and Health, vol. 47, no. 4, pp. 1-17, 2008.

[24] R. S. Mitchell, R. S. Padwal, A. W. Chuck, and S. W. Klarenbach, "Cancer screening among the overweight and obese in Canada," American Journal of Preventive Medicine, vol. 35, no. 2, pp. 127-132, 2008.

[25] H. Wu, K. Zhu, M. Shah, R. J. Lipnick, and T.-C. Kao, "BMI and cervical cancer screening among white, AfricanAmerican, and hispanic women in the United States," Obesity, vol. 14, no. 3, pp. 526-527, 2006.

[26] N. K. Amy, A. Aalborg, P. Lyons, and L. Keranen, "Barriers to routine gynecological cancer screening for White and AfricanAmerican obese women," International Journal of Obesity, vol. 30, no. 1, pp. 147-155, 2006.

[27] T. Østbye, D. H. Taylor Jr., W. S. Yancy Jr., and K. M. Krause, "Associations between obesity and receipt of screening mammography, papanicolaou tests, and influenza vaccination: Results from the Health and Retirement Study (HRS) and the Asset and Health Dynamics Among the Oldest Old (AHEAD) Study," American Journal of Public Health, vol. 95, no. 9, pp. 1623-1630, 2005.

[28] G. D. Datta, G. A. Colditz, I. Kawachi, S. V. Subramanian, J. R. Palmer, and L. Rosenberg, "Individual-, neighborhood-, and state-level socioeconomic predictors of cervical carcinoma screening among U.-S. black women: a multilevel analysis," Cancer, vol. 106, no. 3, pp. 664-669, 2006.

[29] S. S. Coughlin, R. J. Uhler, H. I. Hall, and P. A. Briss, "Nonadherence to breast and cervical cancer screening: what are the linkages to chronic disease risk?" Preventing Chronic Disease, vol. 1, no. 1, p. A04, 2004.

[30] K. R. Fontaine, M. Heo, and D. B. Allison, "Body weight and cancer screening among women," Journal of Women's Health and Gender-Based Medicine, vol. 10, no. 5, pp. 463-470, 2001.

[31] K. R. Fontaine, M. S. Faith, D. B. Allison, and L. J. Cheskin, "Body weight and health care among women in the general population," Archives of Family Medicine, vol. 7, no. 4, pp. 381384, 1998.

[32] K. J. Muus, T. Baker-Demaray, L. R. McDonald et al., "Body mass index and cancer screening in older American Indian and Alaska Native men," Journal of Rural Health, vol. 25, no. 1, pp. 104-108, 2009.

[33] L. L. Adams-Campbell, K. Makambi, C. P. Mouton, J. R. Palmer, and L. Rosenberg, "Colonoscopy utilization in the black women's health study," Journal of the National Medical Association, vol. 102, no. 3, pp. 237-242, 2010.

[34] L. A. Leone, M. K. Campbell, J. A. Satia, J. Michael Bowling, and M. P. Pignone, "Race moderates the relationship between obesity and colorectal cancer screening in women," Cancer Causes and Control, vol. 21, no. 3, pp. 373-385, 2010.

[35] A. S. James, L. Leone, M. L. Katz, L. H. McNeill, and M. K. Campbell, "Multiple health behaviors among overweight, class i obese, and class ii obese persons," Ethnicity and Disease, vol. 18, no. 2, pp. 157-162, 2008.

[36] J. M. Ferrante, P. Ohman-Strickland, S. V. Hudson, K. A. Hahn, J. G. Scott, and B. F. Crabtree, "Colorectal cancer screening among obese versus non-obese patients in primary care practices," Cancer Detection and Prevention, vol. 30, no. 5, pp. 459-465, 2006.

[37] M. Menis, B. Kozlovsky, P. Langenberg et al., "Body mass index and up-to-date colorectal cancer screening among Marylanders aged 50 years and older," Preventing Chronic Disease, vol. 3, no. 3, p. A88, 2006.

[38] D. Vlahov, J. Ahern, T. Vazquez et al., "Racial/ethnic differences in screening for colon cancer: report from the New York cancer project," Ethnicity and Disease, vol. 15, no. 1, pp. 76-83, 2005.

[39] M. Heo, D. B. Allison, and K. R. Fontaine, "Overweight, obesity, and colorectal cancer screening: disparity between men and women," BMC Public Health, vol. 4, article 53, 2004.

[40] A. B. Rosen and E. C. Schneider, "Colorectal cancer screening disparities related to obesity and gender," Journal of General Internal Medicine, vol. 19, no. 4, pp. 332-338, 2004.

[41] L. C. Seeff, M. R. Nadel, C. N. Klabunde et al., "Patterns and predictors of colorectal cancer test use in the adult U.S. population," Cancer, vol. 100, no. 10, pp. 2093-2103, 2004.

[42] M. L. Slattery, A. Y. Kinney, and T. R. Levin, "Factors associated with colorectal cancer screening in a populationbased study: the impact of gender, health care source, and time," Preventive Medicine, vol. 38, no. 3, pp. 276-283, 2004.

[43] A. Chao, C. J. Connell, V. Cokkinides, E. J. Jacobs, E. E. Calle, and M. J. Thun, "Underuse of screening sigmoidoscopy and colonoscopy in a large cohort of US adults," American Journal of Public Health, vol. 94, no. 10, pp. 1775-1781, 2004.

[44] S. S. Cohen, R. T. Palmieri, S. J. Nyante et al., "A review: obesity and screening for breast, cervical, and colorectal cancer in women," Cancer, vol. 112, no. 9, pp. 1892-1904, 2008.

[45] M. M. Amonkar and S. Madhavan, "Compliance rates and predictors of cancer screening recommendations among Appalachian women," Journal of Health Care for the Poor and Underserved, vol. 13, no. 4, pp. 443-460, 2002.

[46] E. J. Simoes, C. J. Newschaffer, N. Hagdrup et al., "Predictors of compliance with recommended cervical cancer screening schedule: a population-based study," Journal of Community Health, vol. 24, no. 2, pp. 115-130, 1999.

[47] B. Levin, D. A. Lieberman, B. McFarland et al., "Screening and surveillance for the early detection of colorectal cancer and adenomatous polyps, 2008: a joint guideline from the American Cancer Society, the US Multi-Society Task Force on Colorectal Cancer, and the American College of Radiology," Gastroenterology, vol. 134, no. 5, pp. 1570-1595, 2008.

[48] C. C. Wee, E. P. McCarthy, and R. S. Phillips, "Factors associated with colon cancer screening: the role of patient factors and physician counseling," Preventive Medicine, vol. 41, no. 1, pp. 23-29, 2005.

[49] M. Bazargan, C. Ani, S. Bazargan-Hejazi, R. S. Baker, and R. Bastani, "Colorectal cancer screening among underserved 
minority population: discrepancy between physicians' recommended, scheduled, and completed tests," Patient Education and Counseling, vol. 76, no. 2, pp. 240-247, 2009.

[50] E. N. Zayat, K. R. Fontaine, and L. J. Cheskin, "Use of preventive health care services by patients with obesity," Obesity Research, vol. 7, no. 2, pp. 223-226, 1999.

[51] C. L. Olson, H. D. Schumaker, and B. P. Yawn, "Overweight women delay medical care," Archives of Family Medicine, vol. 3, no. 10, pp. 888-892, 1994.

[52] S. C. Larsson and A. Wolk, "Obesity and colon and rectal cancer risk: a meta-analysis of prospective studies," American Journal of Clinical Nutrition, vol. 86, no. 3, pp. 556-565, 2007.

[53] A. A. Moghaddam, M. Woodward, and R. Huxley, "Obesity and risk of colorectal cancer: a meta-analysis of 31 studies with 70,000 events," Cancer Epidemiology Biomarkers and Prevention, vol. 16, no. 12, pp. 2533-2547, 2007.

[54] L. A. Anderson, A. A. Eyler, D. A. Galuska, D. R. Brown, and R. C. Brownson, "Relationship of satisfaction with body size and trying to lose weight in a national survey of overweight and obese women aged 40 and older, United States," Preventive Medicine, vol. 35, no. 4, pp. 390-396, 2002.

[55] M. L. Fitzgibbon, L. R. Blackman, and M. E. Avellone, "The relationship between body image discrepancy and body mass index across ethnic groups," Obesity Research, vol. 8, no. 8, pp. 582-589, 2000.

[56] J. S. Haas, G. Fitzmaurice, P. Brawarsky et al., "Association of regional variation in primary care physicians' colorectal cancer screening recommendations with individual use of colorectal cancer screening," Preventing Chronic Disease, vol. 4, no. 4, p. A90, 2007.

[57] C. H. Brouse, R. L. Wolf, and C. E. Basch, "Facilitating factors for colorectal cancer screening," Journal of Cancer Education, vol. 23, no. 1, pp. 26-31, 2008.

[58] I. T. Zajac, A. H. Whibley, S. R. Cole et al., "Endorsement by the primary care practitioner consistently improves participation in screening for colorectal cancer: a longitudinal analysis," Journal of Medical Screening, vol. 17, no. 1, pp. 19-24, 2010.

[59] S. S. Coughlin and T. Thompson, "Physician recommendation for colorectal cancer screening by race, ethnicity, and health insurance status among men and women in the United States, 2000," Health Promotion Practice, vol. 6, no. 4, pp. 369-378, 2005.

[60] P. Brawarsky, D. R. Brooks, L. A. Mucci, and P. A. Wood, "Effect of physician recommendation and patient adherence on rates of colorectal cancer testing," Cancer Detection and Prevention, vol. 28, no. 4, pp. 260-268, 2004.

[61] S. A. Fox, P. J. Murata, and J. A. Stein, "The impact of physician compliance on screening mammography for older women," Archives of Internal Medicine, vol. 151, no. 1, pp. 50-56, 1991.

[62] K. E. Grady, J. P. Lemkau, J. M. McVay, and S. T. Reisine, "The importance of physician encouragement in breast cancer screening of older women," Preventive Medicine, vol. 21, no. 6, pp. 766-780, 1992.

[63] R. R. Love, R. L. Brown, J. E. Davis, L. J. Baumann, S. A. Fontana, and L. A. Sanner, "Frequency and determinants of screening for breast cancer in primary care group practice," Archives of Internal Medicine, vol. 153, no. 18, pp. 2113-2117, 1993.

[64] D. S. May, C. I. Kiefe, E. Funkhouser, and M. N. Fouad, "Compliance with mammography guidelines: physician recommendation and patient adherence," Preventive Medicine, vol. 28, no. 4, pp. 386-394, 1999.
[65] J. H. Price, S. M. Desmond, R. A. Krol, F. F. Snyder, and J. K. O'Connell, "Family practice physicians' beliefs, attitudes, and practices regarding obesity," American Journal of Preventive Medicine, vol. 3, no. 6, pp. 339-345, 1987.

[66] K. D. Bertakis and R. Azari, "The impact of obesity on primary care visits," Obesity Research, vol. 13, no. 9, pp. 1615-1623, 2005. 


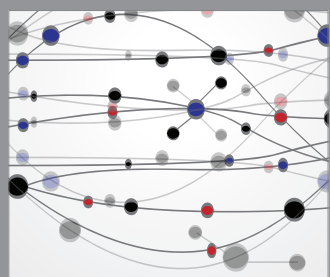

The Scientific World Journal
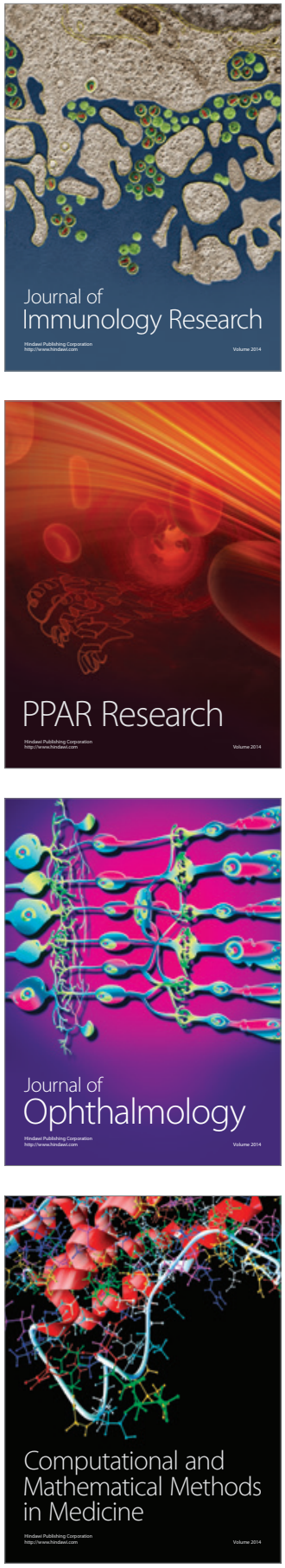

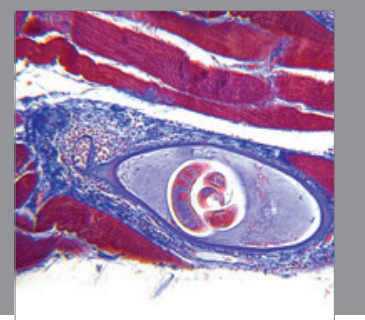

Gastroenterology

Research and Practice
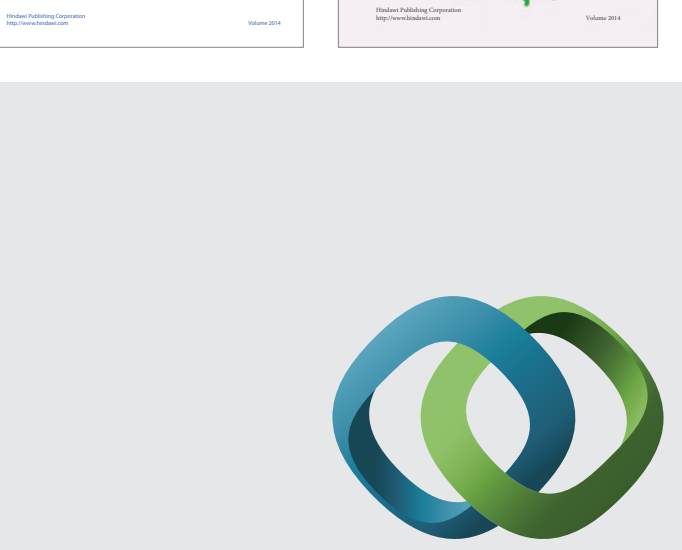

\section{Hindawi}

Submit your manuscripts at

http://www.hindawi.com
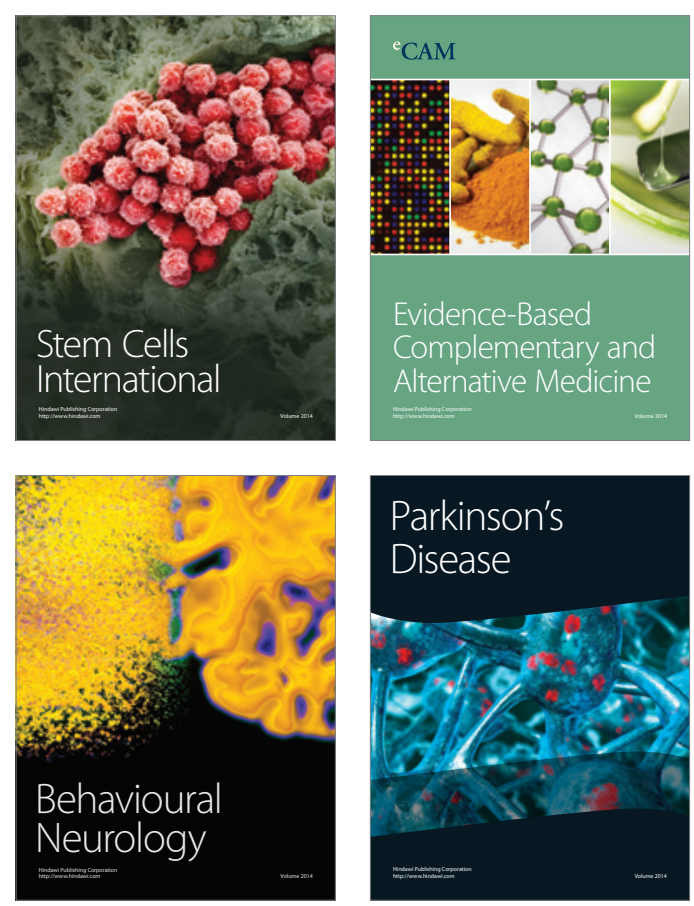

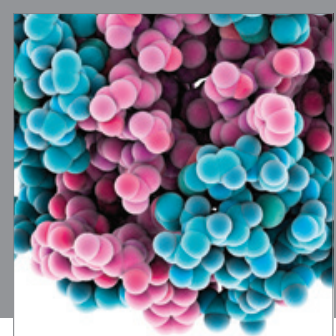

Journal of
Diabetes Research

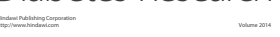

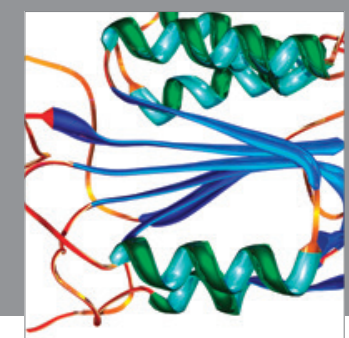

Disease Markers
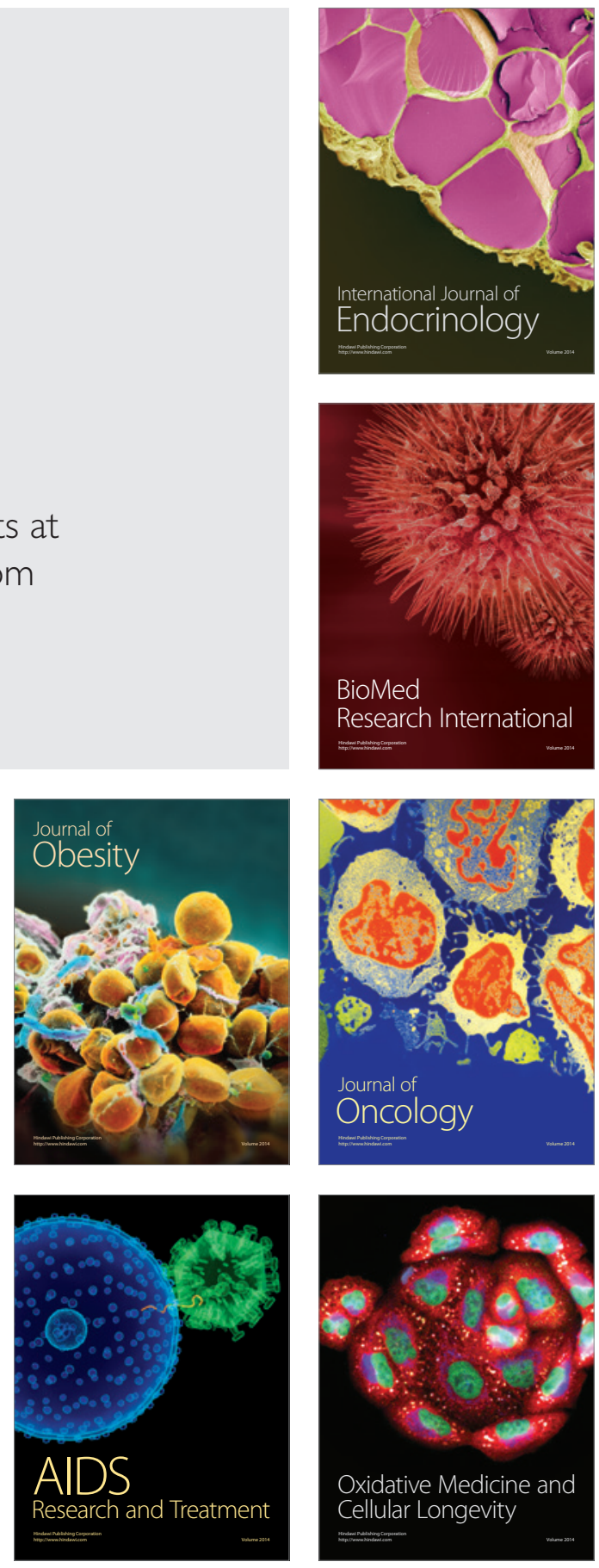